\title{
AL-AWQAF
}

Jurnal Wakaf dan Ekonomi Islam

Vol. 14, No. 2, Tahun 2021

\section{Pendayagunaan Zakat dan Wakaf untuk Mencapai Maqashid al-Syari'ah}

\author{
Amir Sahidin \\ Universitas Darussalam Gontor, Ponorogo, Amirsahidin42003@mhs.unida.gontor.ac.id
}

\begin{abstract}
Zakat is a property right that must be fulfilled by every Muslim who owns property and has fulfilled the conditions. While waqf is the main means in distributing assets or wealth of the people, as well as a substitute for public facilities. Both are Islamic Shari'a that exist for a noble purpose, bringing benefits both in the world and in the hereafter (maqashid al-syari'ab). Therefore, the study of zakat and waqf will be more important if studied with the maqashid al-syari'ah approach. This article discusses the utilization of zakat and waqf to achieve maqashid al-syari'ah. Through a library research study with a descriptive-analytical approach, it can be concluded that the utilization of zakat to achieve maqashid al-syari'ah includes three maqashid, namely: maqashid dini, maqashid ijtima'i, and maqashid iqtishadi. Meanwhile, the utilization of waqf to achieve maqashid al-syari'ab includes general and specific purposes for which wakat is prescribed. Then all should be directed to achieve al-maqashid al-khamsah, in the form of guarding religion, soul, mind, lineage and property.
\end{abstract}

Keywords: zakat, waqf, maqashid al-syari'ah, maqashid al-khamsah.

Abstrak: Zakat merupakan hak harta yang harus ditunaikan oleh setiap Muslim pemilik harta yang telah terpenuhi syarat-syaratnya. Adapun wakaf merupakan sarana utama dalam pendistribusian kekayaan umat dan sebagai pengganti fasilitas publik. Keduanya merupakan syariat Islam yang hadir untuk tujuan mulia, mendatangkan kemaslahatan baik di dunia maupun di akhirat (maqashid al-syariah). Oleh karenanya, kajian tentang zakat dan wakaf akan semakin penting jika dikaji dengan pendekatan maqasbid al-syari'ah. Artikel ini membahas pendayagunaan zakat dan wakaf untuk mencapai maqashid alsyariah. Melalui kajian yang bersifat library reseach dengan pendekatan deskriptif-analisis dapat disimpulkan bahwa pendayagunaan zakat untuk mencapai maqashid al-syari'ah meliputi tiga maqashid, yaitu: maqashid dini, maqashid ijtima'i, dan maqashid iqtishadi. Sedangkan pendayagunaan wakaf untuk mencapai maqashid al-syari'ab meliputi tujuan umum dan khusus disyariatkannya wakaf. Kemudian semua hendaknya diarahkan untuk mencapai al-maqashid al-khamsah, berupa penjagaan terhadap agama, jiwa, akal, keturunan dan harta

Kata Kunci: zakat, wakaf, maqashid al-syari'ah, maqashid al-khamsah.

$$
\begin{aligned}
& \text { ملخص: الزكاة حق ملكية يجب أن يفي به كل مسلم يملك عقارًا استوفى فيه الشروط. وفي حين أن الوقف } \\
& \text { هو الوسيلة الرئيسية في توزيع الأصول أو ثروات الناس، وكذلك كبديل للمرافق العامة. كلاهما شريعة }
\end{aligned}
$$

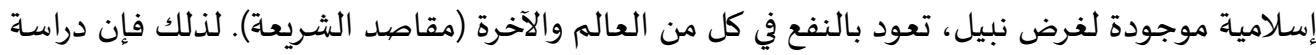




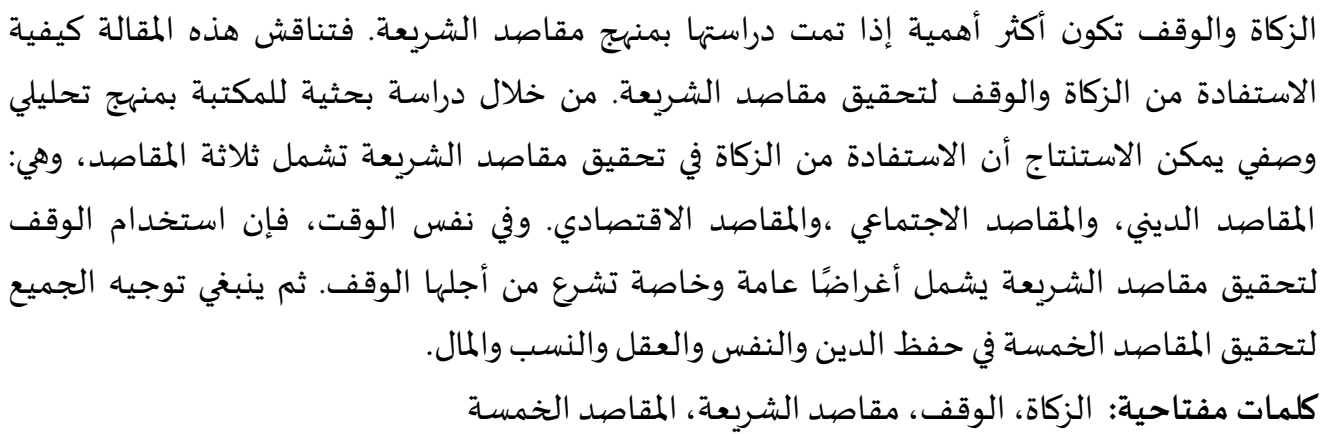

\section{PENDAHULUAN}

Pada dasarnya persoalan ekonomi, kemiskinan dan kesenjangan sosial yang dihadapi masyarakat pada hari ini adalah disebabkan karena kesalahan dalam melihat konsep harta. Mereka mengira bahwa pemilik harta secara hakiki adalah manusia, sehingga tidak ada kekuasaan lebih tinggi darinya yang berhak menyuruh atau melarang dalam menggunakan harta (Halimah, n.d.). Padahal hakikat pemilik harta sebenarnya adalah Tuhan (Allah), sedangkan manusia hanya sebagai pekerja dan orang yang menguasainya (Halimah, n.d.). Allah pun menurunkan syariat Islam untuk mengatur masalah harta tersebut yang di antaranya dengan adanya syariat zakat dan wakaf.

Bagi seorang Muslim kajian tentang zakat dan wakaf merupakan perkara penting. Zakat merupakan hak harta yang harus ditunaikan oleh setiap Muslim pemilik harta, telah sampai pada nishab dan terpenuhi syarat-syaratnya (Al-Maqdisi, 1967). Ia juga merupakan salah satu rukun dari lima rukun Islam (Al-Maqdisi, 1967). Sedangkan wakaf merupakan sarana utama dalam pendistribusian aset atau kekayaan umat serta sebagai pengganti fasilitas publik (Fauzia, 2019). Keduanya merupakan syariat Islam yang hadir untuk tujuan mulia, mendatangkan kebaikan baik di dunia maupun di akhirat (maqashid al-syariab) (Al-Syatibi, 1997).

Kajian tentang zakat dan wakaf akan semakin penting dan indah, jika ia dikaji dengan pendekatan maqashid al-syari'ah. Karena setiap hukum Islam selalu mendatangkan kebaikan, baik kebaikan dunia maupun akhirat (Al-Syatibi, 1997), untuk kesejahteraan masyarakat Muslim hingga tumbuh menuju kebahagiaan dengan merasa bangga terhadap syariat (Zaidan, 2002). Oleh sebab itu, artikel ini membahas terkait pendayagunaan zakat dan wakaf untuk mencapai maqashid al-syariah. Kajian ini dilakukan untuk menampakan sisi keindahan syariat Islam terkait zakat dan wakaf, sehingga seseorang akan memiliki kesadaran untuk menjalankan syariat tersebut dengan kesadaran agama, hati dan intelektual.

\section{TINJAUAN PUSTAKA}

\section{Tinjauan Umum Zakat dan Wakaf}

Secara bahasa zakat merupakan bentuk mashdar dari kata zakka-yuzakki, zakah yang artinya alnama atau tumbuh (A. bin F. Al-Razi, 1979). Imam al-Nawawi berkata, zakat secara bahasa berarti berkembang dan mensucikan. Berkembangnya harta yang dizakati tidak dapat dilihat 
dengan mata dan ia berfungsi membersihkan dosa-dosa orang yang menunaikannya (AlNawawi, 1392). Senada dengan ungkapan tersebut, Ibnu Manzur berkata bahwa asal kata zakat secara bahasa berarti sanjungan, barakah, berkembang dan mensucikan (Mandzur, 1999).

Adapun pengertian zakat secara istilah fikih di antaranya sebagaimana dikatakan oleh Ibnu Qudamah bahwa zakat adalah hak dari harta yang harus ditunaikan dan zakat merupakan salah satu rukun dari rukun-rukun Islam (Al-Maqdisi, 1967). Adapun Shahibul Hawi berkata bahwa zakat yaitu sebuah sebutan untuk pengambilan sesuatu yang khusus, dari harta yang khusus, dengan sifat yang khusus, dan diperuntukkan kepada kelompok yang khusus (AlBaghdadi, 1999). Ia merupakan kewajiban yang Allah tetapkan kepada setiap Muslim pemilik harta yang telah sampai pada nishab dan terpenuhi syarat-syaratnya. Hal ini sebagaimana firman Allah Ta'ala, "Ambillah zakat dari sebagian barta mereka, dan dengan zakat itu kamu mensucikan mereka." (Qs. Al-Taubah: 103) Juga sabda Rasulullah, berbunyi, "Islam dibangun di atas lima rukun: bersaksi bahwa tiada Illah selain Allah dan Mubammad adalah utusan Allah, mendirikan shalat, menunaikan rakat, haji ke Baitullah dan puasa di bulan Ramadhan." (Al-Bukhari, 1422).

Adapun wakaf secara bahasa adalah menahan (Mandzur, 1999). Sedangkan secara istilah, wakaf yaitu menahan harta Allah yang memungkinkan untuk diambil manfaat darinya, disertai tetapnya harta tersebut (Muflih, 1997). Dalam kalimat lain dapat dipahami sebagai penahanan harta sehingga tidak bisa diwarisi, dijual, maupun dihibahkan, dan menyerahkan hasilnya kepada penerima wakaf. Wakaf merupakan perkara sunnah dan dianjurkan. Hal ini sebagaimana firman Allah Ta'ala, "Kecuali jika kamu mau berbuat baik kepada saudara-saudaramu seagama." (Qs. Al-Ahzab: 6) Juga sabda Rasulullah, berbunyi, "Bila anak keturunan Adam meninggal dunia maka terputuslah seluruh amalnya kecuali tiga: sedekah jariah, ilmu yang bermanfaat dan anak shalib yang senantiasa mendoakannya." (Al-Naisaburi, n.d.) Di antara sedekah jariah di sini adalah mewakafkan rumah, tanah, masjid dan lainnya (Jazairi, 2017).

\section{Tinjauan Umum Maqashid al-Syari'ah}

Secara kebahasaan, maqasid al-syari'ah terdiri dari dua kata, yaitu maqashid dan al-syari'ah. Secara etimologi maqashid adalah bentuk jamak dari maqshad (A. bin F. Al-Razi, 1979) yang artinya adalah makna dan tujuan yang Allah maksud (Al-Raisuni, 2010). Sedangkan syari'ah adalah pecahan kata dari syara'a yang artinya adalah sumber air (Mandzur, 1999), menetapkan, jalan, masuk, dan tunduk (M. Al-Razi, 1999). Dalam memaknai syari'ah ini, Syekh Yusuf alQardhawi mengatakan bahwa syariah menurut para ulama mengandung dua arti, pertama: seluruh agama yang mencakup aqidah, ibadah, adab, akhlak, hukum dan muamalah. Dengan kata lain, syari'ah mencakup ushul dan furu, akidah dan amal, serta teori dan aplikasi. Mencakup seluruh isi keimanan dan akidah dan mencakup sisi lain seperti ibadah, muamalah dan akhlak yang dibawa islam serta dirangkum dalam al-Qur'an dan sunnah untuk kemudian dijelaskan oleh ulama akidah, fiqkih, dan akhlak. Kedua: sisi hukum yang bersifat amal di dalam agama Islam, seperti ibadah dan muamalah yang mencakup hubungan dan ibadah kepada Allah. Serta mencakup juga urusan keluarga (al-abwal as-syahsiyah), masyarakat, umat, negara, hukum dan hubungan luar negri (Al-Qardhawi, 2008). Dari sini dapat dikatakan bahwa maqasid al-syariah secara etimologi adalah maksud atau tujuan dari setiap syariat yang Allah tetapkan bagi manusia. 
Adapun maqashid al-syariah secara terminologi menurut Syekh Yusuf al-Qardhawi, tujuantujuan yang menjadi target nash-nash dan hukum-hukum partikular untuk direalisasikan dalam kehidupan manusia, baik berupa perintah, larangan, ataupun kebolehan, untuk individu, keluarga, jamaah dan umat (Al-Qardhawi, 2008). Ibnu Taimiyah menambahi, apapun yang dimaksud dari larangan Allah pasti akan berakibat buruk, dan sebaliknya, apapun perintah Allah pasti berakibat baik, keduanya dapat terlihat dari hikmah perintah dan larangan-Nya (Taimiyyah, 1995). Oleh karenanya Imam al-Syatibi jauh-jauh hari menerangkan dengan tegas, syariat itu bertujuan untuk mewujudkan kemashlahatan manusia di dunia dan di akhirat (Al-Syatibi, 1997). Dari beberapa penjelasakan tersebut, dapat disimpulkan bahwa maqashid alsyari'ah adalah, tujuan dari setiap syariat yang Allah tetapkan bagi manusia, baik individu, jamaah dan umat, berupa perintah, larangan ataupun kebolehan, untuk mendatangkan maslahat dan mencegah mudarat mereka di dunia dan akhirat.

Kemudian, kemaslahatan dalam maqashid al-syariah terbagi menjadi tiga macam yaitu: dharuriyyat, hajiyat dan tahsiniyat (Al-Ghazali, 1993; Al-Syatibi, 1997). Dharuriyyat atau maslahat primer adalah sesuatu yang harus ada demi tegaknya kebaikan dan kesejahteraan, baik di dunia maupun akhirat (Al-Ghazali, 1993; Al-Syatibi, 1997). Hajiyat atau maslahat sekunder adalah sesuatu yang dibutuhkan untuk mendatangkan kelapangan dan menghilangkan kesempitan. Sedangkan tabsiniyat atau maslahat tersier adalah sesuatu berkenaan dengan kebiasaan-kebiasaan baik dan menghindari kebiasaan-kebiasaan buruk berdasarkan pertimbangan akal sehat, hal ini sering disebut dengan akblak al-karimah (Al-Syatibi, 1997). Ketiganya merupakan dasar utama yang menjadi tiang syariat. Al-Syatibi menerangkan bahwa ketiga maslahat ini tidak diragukan lagi ketetapannya dalam agama bagi seorang yuris yang hendak melakukan ijtihad, dan semuannya dianggap sebagai maqashid al-syariah (Al-Syatibi, 1997).

Lebih spesifik lagi, maqashid al-syari'ah pada tingkat dharuriyyat dibagi menjadi lima unsur pokok yang biasa disebut dengan istilah al-maqashid al-khamsah, al-dharuriyyat al-khams atau alkulliyyat al-khams (Al-Ghazali, 1993; Al-Syatibi, 1997; Al-Yubi, 1430; Asyur, 2011). Pertama adalah hifdh al-din (menjaga agama), maksudnya menjaga norma agama setiap individu umat Muslim dari hal-hal yang mengotorinya, baik dari sisi akidah maupun amal. Juga dengan tindakan preventif terhadap setiap potensi yang dapat meruntuhkan prinsip-prinsip agama yang qathi (Asyur, 2011). Penjagaan terhadap agama merupakan penjagaan paling urgen di antara penjagaan terhadap perkara lainnya, bahkan ia merupakan inti dan ruh dari seluruh maqashid (Abdurrahman, 2002). Adapun maqashid selain itu merupakan cabang-cabang yang dibutuhkan untuk menjaga eksistensi pokoknya (agama) (Al-Yubi, 1430). Kedua adalah hifdh al-nafs (menjaga jiwa), maksudnya melindungi setiap individu dan masyarakat secara kolektif dari segala hal yang dapat mengancam jiwa (Asyur, 2011). Penjagaan terhadap jiwa sangat diperhatikan oleh al-Syari' (Allah), sehingga Dia memberikan hukum-hukum yang dapat menjaga eksistensinya, seperti adanya syariat kisas bagi para pembunuh (Abdurrahman, 2002).

Ketiga adalah hifdh al-'aql (menjaga akal), maksudnya mencegah terjadinya khalal (cacat) pada akal yang dapat mengakibatkan kerusakan besar disebabkan ketidakdisiplinan akal dalam berfikir (Asyur, 2011). Syariat Islam memiliki perhatian sangat besar dalam menjaga akal, sebab akal memiliki peran sangat urgen dalam menumbuhkembangkan semangat menggali 
nilai-nilai agama. Oleh karenanya, al-Syâri' (Allah) mengharamkan minumam memabukkan yang dapat merusak akal, seperti khamr, narkotika dan semisalnya (Al-Hasani, 1995). Keempat adalah hifdh al-nasl (menjaga keturunan), maksudnya melestarikan kelangsungan generasi dengan menghindari setiap perkara yang dapat memutus kelangsungan hidup (Asyur, 2011). Oleh karena itu, al-Syari' (Allah) mensyariatkan pernikahan dan melarang perbutan zina dengan mensyariatkan hukuman hudud bagi pelakunnya. kelima adalah hifdh al-mal (menjaga harta), maksudnya menjaga harta dengan mengembangkan sumber-sumber perekonomian rakyat, menjamin hak milik pribadi dan menjaga keamanan harta tersebut (Asyur, 2011). Oleh sebab itu, al-Syari' mensyariatkan muamalah dan adanya hukum potong tangan bagi seorang pencuri (Abdurrahman, 2002). Kesemua maqashid ini merupakan perkara yang sangat urgen untuk senantiasa dijaga eksistensinya. Jika kelimanya tidak dijaga, maka akan menimbulkan kerusakan di dunia dan kesengsaraan di akhirat.

Maqashid al-syarîah pada tingkatan dharuriyyat yang dijelaskan oleh para ulama pada hakikatnya tidak hanya terbatas pada kelima hal tersebut, akan tetapi lebih luas dari itu. Sebagaimana Jamaluddin Athiyyah yang melakukan metamorfosa terhadap lima maqashid tersebut menjadi lebih luas. Ia mengklasifikasikannya menjadi empat devisi yang lebih spesifik, yaitu individu, keluarga, masyarakat dan kemanusiaan (Athiyyah, 2003). Keempat divisi ini kemudian diperinci menjadi dua puluh poin di antaranya adalah, ranah individu meliputi: penjagaan jiwa, penjagaan akal, penjagaan agama, penjagaan kehormatan dan penjagaan harta. Ranah keluarga meliputi: pengaturan hubungan antara individu, penjagaan ras, kenyamanan, penjagaan keturunan, pendidikan keagamaan, penguatan hubungan antar anggota keluarga dan penjagaan keuangan keluarga. Ranah masyarakat meliputi: penguatan hubungan kemasyarakatan, keamanan, keadilan sosial, pendidikan agama dan akhlak, tolongmenolong/asuransi, penyebaran ilmu dan keadilan harta publik. Adapun ranah kemanusiaan meliputi: upaya saling mengenal dan mengetahui, penetapan pemimpin (khalifah), kedamaian internasional, pemenuhan hak-hak manusia, dan penyebaran dakwah Islam (Athiyyah, 2003).

\section{METODOLOGI PENELITIAN}

Penelitian ini merupakan suatu kajian yang bersifat library reseach dengan pendekatan deskriptif-analisis. Data-data penelitian dikumpulkan melalui penelusuran kepustakaan, kemudian dianalisis secara deskriptif untuk menjawab pertanyaan penelitian.

\section{HASIL DAN PEMBAHASAN}

\section{Pendayagunaan Zakat Untuk Mencapai Maqashid Al-Syari'ah}

Pendayagunaan zakat dapat dilihat dari terealisasikannya maqashid al-syari'ah atau tujuan dari pelaksanaan syariat tersebut. Maqashid atau tujuan dari zakat terdiri dari tiga maqashid, yaitu: maqashid dini (agama), maqashid ijtima'i (kemasyarakatan) dan maqashid iqtishadi (ekonomi) (Urjah, 2015). Adapun penjelasannya rincinya yaitu sebagai berikut:

\section{Maqashid zakat yang bersifat keagamaan (maqashid dini).}

Zakat memiliki maqashid rubiyah yang sangat tinggi, dengannya iman seorang Muslim semakin bertumbuh kembang. Hal itu karena semakin dekat hubungannya ia dengan sang Pencipta dan zakat menjadi pengikat antara ia dengan Rabbnya. Untuk mencapai tujuan-tujuan 
tersebut, Islam menjadikan syariat zakat sebagai salah satu dari lima rukunnya. Hal ini tentu demi kemaslahatan manusia baik di dunia maupun di akhirat. Adapun maqashid zakat yang bersifat keagamaan yaitu, pertama: Sebagai bentuk ibadah kepada Allah Ta'ala dengan menunaikan kewajiban, berupa mengeluarkan sejumlah bagian dari harta yang dimiliki (Ghufaili, 2008). Maqashid dari adanya sebuah kewajiban tersebut adalah supaya manusia melaksanakan kewajiban dengan tunduk dan patuh pada perintah Allah. Tujuan ini merupakan tujuan tertinggi dari adanya sebuah syariat (Al-Syatibi, 1997).

Kedua: Menjaga eksistensi lima hal pokok atau maqashid al-khams, yaitu; hifdh al-din, hifdh al-nafs, bifdh al 'aql, hifdh al-nasl, dan hifdh al-mal. Bentuk hifdh al-din adalah untuk menjaga agama dan menyebarkannya di muka bumi dengan adanya zakat, karena zakat bentuk ketaatan seorang kepada Allah berupa menjalankan perintahnya dan menjauhi larangannya, dan dengan zakat pula dapat melunakkan hati manusia sehingga dapat menerima dakwah Islam. Bentuk hifdh alnafs yaitu menjaga masyarakat dari kelaparan, kelemahan dan kematian karena kekurangan. Bentuk hifdh al-'aql yaitu dengan membantu anak-anak dari keluarga yang fakir dan miskin untuk sekolah dengan menjadikannya sebagai mustahik zakat (berhak menerima zakat). Bentuk hifdh al-nasb yaitu membantu para fakir miskin ketika mereka ingin menikah, menjaga kehamilan mereka dengan memberi mereka makan. Bentuk hifdh al-mal yaitu dengan zakat, harta akan bertambah dengan adanya barakah, membuang yang syubhat dari harta yang dimiliki (al-Zubair, n.d.).

Ketiga: Sebagai bentuk rasa syukur kepada Allah. Zakat merupakan ibadah maliyah (berupa harta) di mana Islam mensyariatkannya guna mengingatkan manusia supaya bersyukur kepada Allah atas nikmat nikmat harta yang dikaruniakan. Allah sedang menguji kadar keimanan dan ketaqwaan mereka dengan zakat, apakah manusia melaksanakan zakat atau justru enggan melaksanakannya (Khautani, 1418). Allah berfirman, "Dan berilah mereka dari barta Allah yang dikaruniakan padamu” (Qs. Al-Nur: 33). Keempat: Membersihkan jiwa manusia dari noda bakhil, kikir, jahat dan tamak. Allah Ta'ala menciptakan manusia dengan fitrah mencintai harta, sehingga mayoritas manusia condong bersifat bakhil (Qs. Al-Nisa': 128; Qs. Al-Isra': 100). Oleh karena itu zakat mengajak manusia untuk mengikis sifat tersebut dengan dorongan iman sehingga ia menjadi orang yang beruntung di dunia maupun di akhirat (Qardhawi, n.d.). Kelima: untuk menyebarkan dakwah Islam. Zakat merupakan salah satu wasilah untuk menyiarkan dakwah Islam, menyeru manusia supaya kembali kepada Allah. Dakwah dengan zakat dapat dilakukan dengan cara menggunakan dana zakat untuk membiayai para dai, mendirikan madrasah, mendirikan lembaga-lembaga dakwah, serta membangun jamaah yang kuat sebagai tempat bernaung masyarakat Muslim (Al-Qardhawi, 2001).

\section{Maqashid zakat yang bersifat kemasyarakatan (maqashid ijtima'iyyah)}

Ada beberapa maqashid ijtima'zyyah dari adanya syariat zakat, di antaranya adalah, pertama: Mempererat ikatan sosial di antara kaum Muslimin. Tujuan zakat yaitu supaya setiap Muslim merasa bertanggung jawab terhadap saudara Muslim lainnya, merasakan apa yang mereka rasakan, sehingga ia melakukan hal yang dapat membantunya, menjaganya dari pahitnya hidup. Dengan demikian si fakir tidak menaruh dengki kepada si kaya, bahkan mereka akan merasa bahwa mereka semua bersaudara, satu keluarga yang saling tolong-menolong dan berpegang teguh dengan tali Allah (Ibrahim, 1999). Zakat menjadikan masyarakat saling 
berkasih sayang, saling terikat satu sama lain, tercipta mawaddah wa rabmah di antara mereka, sebuah masyarakat yang saling membantu mencukupi kebutuhan pokok masing-masing. Dengan demikian terciptalah keeratan ikatan sosial di antara kaum Muslimin seluruhnya.

Kedua: Menyelesaikan problem meminta-minta di masyarakat. Islam memerintahkan kepada manusia supaya menjaga kehormatannya dan menahan diri dari meminta-minta. Sebab meminta-minta merupakan suatu kehinaan, yaitu kehinaan meminta-minta itu sendiri dan kehinaan ketika permintaannya justru ditolak begitu saja. Yusuf al-Qardhawi menjelaskan bahwa cara mengatasi problem di atas ada dua cara: menyiapkan pekerjaan yang sesuai untuk mereka atau menanggung biaya hidup yang sesuai untuk mereka. Dengan adanya zakat maka hidup seseorang dapat ditanggung jika kondisi orang tersebut lemah tidak dapat bekerja (Qardhawi, n.d.). Ketiga, Mengatasi problem kesenjangan sosial. Kesenjangan sosial dalam sejarah kemanusiaan bukanlah hal baru. Dari zaman ke zaman keadaan itu selalu terjadi. Namun, Islam memberikan tuntunan untuk keluar dari keadaan yang tidak menyenangkan itu. Secara ekonomis, untuk mendekatkan antara yang berlebih dengan kekurangan, Islam memiliki konsep kewajiban membayar zakat (Muhammad Maksum, 2008).

\section{Maqashid zakat yang bersifat ekonomi (maqashid iqtishadiyyah)}

Ada beberapa maqashid iqtishadiyah dari zakat di antaranya, yaitu, pertama: Zakat dapat mencegah dari pemendaman harta. Hal ini karena Allah Ta'ala memerintahkan kaum Muslimin untuk membayar zakat dan mengecam penimbun harta yang tidak menginfakkan hartanya di jalan Allah (Qs. Al-Taubah: 34-35). Zakat memberikan peran penting dalam memerangi penimbunan harta, ia memotivasi manusia supaya mengembangkan hartanya dan memberikan manfaat kepada orang lain dengan adanya syariat zakat. Kedua: Zakat dapat mencegah kefakiran. Termasuk dari tujuan utama syariat zakat di antaranya yaitu untuk mengatasi dan mengangkat kefakiran, atau meminimalisir angka kemiskinan. Zakat tidak hanya diberikan dalam jumlah yang hanya cukup untuk makan, sehingga terus bergantung pada zakat, namun yang diinginkan adalah agar ia mampu mencukupi kebutuhannya sendiri dan mengembangkan potensinya (Ibrahim, 1999).

Oleh karena itu, Islam menyediakan sistem jaminan sosial berdasarkan kelembagaan zakat. Islam mengenalkan konsep tanggung jawab berjenjang. Pada level pertama, seorang individu bertanggung jawab terhadap kondisi dirinya untuk tetap bisa hidup dalam kondisi maslahah minimum. Pada tahap kedua, tanggung jawab akan berpindah pada keluarga dan kerabat dekat jika diri telah tidak mampu; tahap ketiga, ada pada tanggung jawab kolektif (fardu kifayah), dan keempat ada pada negara. Sedangkan, zakat merupakan bentuk tanggung jawab sosial terhadap anggota masyarakat. Sistem jaminan sosial berbasis zakat berbeda dengan konsep barat, seperti walfare state yang dibangun atas dasar iuran (misalnya, iuran dana pensiun atau hari tua) ataupun pajak. Sistem jaminan sosial zakat didasarkan pada konsep persaudaraan dan kepedulian sesama untuk mewujudkan komitmen ekonomi yang saling menguntungkan dan harmoni sosial (Sadeq, 1983). Sistem jaminan sosial zakat tidak akan membiarkan kelompok miskin menjadi ketergantungan, namun ada upaya untuk meningkatkan kondisi mustahik (penerima) menjadi muzakki (pemberi). 


\section{Pendayagunaan Wakaf Untuk Mencapai Maqashid Al-Syari'ah}

Wakaf memiliki maqashid atau tujuan yang mulia. Tujuan tersebut dapat dibagi menjadi dua, yaitu: tujuan umum dan tujuan khusus disyariatkannya wafat. Tujuan umum syariat wakaf adalah mendapatkan serta menemukan sumber daya yang permanen dan berkelanjutan untuk mencapai tujuan yang diperbolehkan, untuk kemaslahatan tertentu (Al-Sya'bi, 1420). Sedangkan tujuan khususnya di antaranya yaitu: pertama, wakaf menjamin harta menjadi kekal dan dapat senantiasa termanfaatkan untuk jangka waktu yang lama, sebab sesuatu yang diwakafkan ia terikat selamanya dengan tujuan dari wakaf itu sendiri. Kedua, menjadi amal kebaikan dari pewakaf kepada orang yang menerima wakaf, sebab Islam selalu memotivasi umatnya untuk senantiasa berbuat baik, sedangkan kebaikan merupakan modal untuk melanggengkan dan menyambung tali persaudaraan di antara manusia, menjadikan mereka saling mencintai serta menghilangkan permusuhan yang terjadi di antara mereka. Ketiga, menjadi amal jariyah oleh pihak yang berwakaf hingga ia wafat dan berada di alam kubur. Keempat, Sebagai bentuk melaksanakan perintah Allah dan Nabi-Nya (Al-Kubaisi, 1997). Kelima, dalam wakaf terdapat unsur tolong-menolong dalam kebaikan untuk menanggung anak yatim, orang-orang fakir dan miskin. Inilah yang kemudian disebut sebagai takaful dan kepedulian sosial, yang keduanya merupakan perkara dianjurkan dalam Islam (Qs. Al-Maidah: 3). Keenam, wakaf merupakan bentuk amal ketaatan yang dapat mendekatkan pelakunya kepada Allah (Al-Nail, 1978).

Adapun pendayagunaan zakat dan wakaf berdasarkan urutan maqashid al-khams yaitu (alQaqib, n.d.): pertama: menjaga eksistensi agama. Di antara metode pendayagunaan wakaf untuk hifdh al-din yaitu dengan cara membangun masjid, menanggung biaya hidup para dai yang berjuang mengajar manusia, mencetak mushaf dan membagikannya pada semua kaum Muslimin, membiayai para penghafal al-Qur'an, mencetak kitab-kitab hadis dan ilmu syar'i kemudian membagikannya pada kaum Muslimin, menyelenggarakan daurah-daurah ilmiah dengan tujuan menyeru masyarakat supaya mengikuti al-Qur'an dan sunnah, serta mengingatkan bahaya kesyirikan, membangun sekolah-sekolah berbasis wakaf, baik dalam bentuk pembangunan material maupun ilmiah, dan menyelenggarakan musabaqab hifdh alQur'an maupun hadis.

Kedua, Menjaga eksistensi akal. Di antara bentuk pendayagunaan wakaf untuk bifdh al-aql yaitu mendirikan pusat-pusat pengembangan pemikiran dan keterampilan, memotivasi dan memberikan dorongan untuk anak-anak yang berbakat, menyelenggarakan kompetisi ilmiah dalam penemuan modern, mendirikan pusat penelitian khusus di universitas-universitas terkait ilmu-ilmu yang bermanfaat baik di dunia maupun di akhirat, mendirikan sekolah yang unggul, mendirikan media center yang sesuai dengan ketentuan syariat Islam, mendirikan perpustakaan ilmiah khusus dalam berbagai seni pengetahuan. Ketiga. menjaga eksistensi diri dan nasab. Di antara bentuk pendayagunaan wakaf untuk hifdh al-nafs dan hifdh al-nasb, yaitu dengan membantu menanggung biaya pernikahan bagi mereka yang tidak mampu secara finansial. Menyelenggarakan kursus pra nikah, mengadakan sosialisasi dan konsultasi hukum, sosial, dan medis bagi pasangan yang baru saja menikah agar anak keturunannya bebas dari cacat, mendukung program pelatihan kesehatan bagi ibu hamil untuk keselamatan mereka dan bayi yang dikandung. Keempat, menjaga eksistensi harta. Di antara bentuk pendayagunaan 
wakaf untuk hifdh al-mal yaitu mendirikan pabrik dan mempekerjakan kaum Muslimin di pabrik tersebut (al-Qaqib, n.d.).

\section{PENUTUP}

Dari berbagai penjelasan di atas, dapat disimpulkan bahwa zakat merupakan hak harta yang harus ditunaikan setiap Muslim pemilik harta dan telah terpenuhi syarat-syaratnya. Sedangkan wakaf merupakan sarana utama dalam pendistribusian aset atau kekayaan umat serta sebagai pengganti fasilitas publik. Keduanya merupakan syariat Islam yang hadir untuk tujuan mulia, mendatangkan kebaikan baik di dunia maupun di akhirat. Oleh karenanya zakat dan wakaf harus diarahkan atau didayagunakan untuk mencapai maqashid al-syariah. Adapun pendayagunaan zakat untuk mencapai maqashid al-syariah meliputi tiga maqashid, yaitu: maqashid dini, maqashid ijtima'i, dan maqashid iqtishadi. Sedangkan pendayagunaan wakaf untuk mencapai maqashid al-syari'ah meliputi tujuan umum dan tujuan khusus disyariatkannya wakaf. Tujuan umum syariat wakaf yaitu mendapatkan serta menemukan sumber daya yang permanen dan berkelanjutan untuk mencapai kemaslahatan tertentu. Sedangkan tujuan khususnya di antaranya yaitu: pertama, wakaf menjamin harta menjadi kekal. Kedua, menjadi amal kebaikan dari pewakaf kepada orang yang menerima wakaf. Ketiga, menjadi amal jariyah. Keempat, Sebagai bentuk melaksanakan perintah Allah dan Rasul-Nya. Kelima, dalam wakaf terdapat unsur tolong-menolong. Keenam, wakaf merupakan bentuk amal ketaatan yang dapat mendekatkan pelakunya kepada Allah. Selain itu semua, baik zakan maupun wakaf hendaknya diarahkan untuk mencapai maqashid al-khams, berupa penjagaan terhadap agama, jiwa, akal, keturunan dan harta.

\section{DAFTAR PUSTAKA}

Abdurrahman, A. A. bin. (2002). 'Im Maqashid al-Shari'. Riyad: Maktabah al-Mulk Fahd.

Al-Baghdadi, A. bin M. (1999). al-Hawi al-Kabir fi Fiqh Madð̧ab al-Imam al-Syafi'i. Beirut: Dar al-Kutub al-'Ilmiyyah.

Al-Bukhari, M. bin I. (1422). Shabih al-Bukhari. Beirut: Dar Thuqi al-Najah.

Al-Ghazali, A. H. (1993). al-Mustashfa. Beirut: Dar al-Kutub al-'Ilmiyyah.

Al-Hasani, I. (1995). Nadhariyat al-Maqashid Inda al-Imam Muhammad al-Thabir bin 'Ashur. Herdon: The Internetional Institute of Islamic Thought.

Al-Kubaisi, M. A. (1997). Ahkam al-Waqfi fi al-Syari'ah al-Ilslamiyyah. Baghdad: al-Irsyad.

Al-Maqdisi, ibnu Q. (1967). al-Mughni. Kairo.

Al-Nail, Y. I. (1978). Miftah al-Dirayah li Abkam al-Waqfi wa al 'Athaya. Dubai: al-Auqaf wa alSyu'un al-Islamiyyah.

Al-Naisaburi, M. bin H. (n.d.). Shabih Muslim. Beirut: Dar Ihya' al-Turats.

Al-Nawawi, Y. bin S. (1392). al-Minhaj Syarh Shabih Muslim bin al-Hijaj. Beirut: Dar Ihya' alTurats.

Al-Qardhawi, Y. (2001). fi Fiqh al-Aqalliyat al-Muslimah. Kairo: Dar al-Syuruq.

Al-Qardhawi, Y. (2008). Dirasah fi Figh Maqashid al-Syari ah. Kairo: Dar al-Syuruq.

Al-Raisuni, A. (2010). Muhadharat fi Maqashid al-Syari ah. Kairo: Dar al-Kalimah.

Al-Razi, A. bin F. (1979). Mu'jam Maqayis al-Lughah. Damaskus: Dar al-Fikr. 
Al-Razi, M. (1999). Mukhtar al-Shihah. Beirut: Dar al-Namudzajiyah.

Al-Sya'bi, A. A. J. (1420). al-Waqf Mafhumubu wa Maqashidubu. Saudi: Wuzarah al-Auqaf wa alSyu'un al-Islamiyyah.

Al-Syatibi, A. I. (1997). al-Muwafaqat. Kairo: Dar Ibnu Affan.

Al-Yubi, M. S. (1430). Maqashid al-Syari'ah al-Islamiyyah wa 'Alaqatuba bi al-Adillah al-Syar'iyyah. Riyad: Dar Ibnu Jauzi.

Asyur, M. T. bin. (2011). Maqashid al-Syari'ah al-Islamiyyah. Beirut: Dar al-Kutub al-Lubnani.

Athiyyah, J. (2003). Nahwa Taf'il Maqashid al-Syari'ah. Beirut: Dar al-Fikr.

Fauzia, A. (2019). Filantropi Islam sejarah dan kontestasi masyarakat sipil dan negara di indonesia. Yogyakarta: Gading Publishing.

Ghufaili, A. bin M. al. (2008). Nawazil al-Zakat. Saudi: Dar al-Maiman.

Halimah, A. M. M. (n.d.). Kaifa Tubafidh 'ala Malik wa Kaifa Tanmiyatubu.

Ibrahim, M. H. (1999). Dauru az Zakah fi Kbidmatil Mujtama'. Kairo: Dar Gharib.

Jazairi, A. B. J. al. (2017). Minhajul Muslim, terj: Salafuddin Abu Sayyid, dkk. Solo: Pustaka Arafah.

Khautani, M. bin J. bin A. Al. (1418). al-Taujihat al-Tarbawiyyah li Faridhati al-Zakah. Makkah: Jami'ah Umul Qura.

Mandzur, I. (1999). Lisan al-'Arab. Beirut: Dar al-Namudzajiyah.

Muflih, B. ibnu. (1997). al-Mubdi' fi Syarh al-Muqni'. Beirut: Dar al-Kutub al-'Ilmiyyah.

Muhammad Maksum, D. (2008). Fikih Zakat on SDGS. Mumtaz Press.

Qardhawi, Y. al. (n.d.). Fiqh al-Zakah. Beirut: Muassasah al-Risalah.

Sadeq, A. A.-H. (1983). A Survey of the institutions of zakah: issues, theories and Administration, IRTI.

Taimiyyah, I. (1995). Majmu' al-Fatawa. Madinah: Majma' al-Mulk Fahd.

Urjah, L. S. M. A. (2015). Daf'u al-Zakah li Ushul wa al-Furu' fi al-Figh al-Islamy. Gazza: risalah majiztir Jami'ah al-Islamiyyah.

Zaidan, A. K. (2002). Ushul al-Da'wah. Beirut: Muassasah al-Risalah.

\section{Internet}

Al-Zubair, Abdullah. (n.d.). "al Maqashid asy Syar'iyyah fi Tasyri az Zakab", http://www.azubair.com/azubair/index.php/main/index/17/5/contents, (diakses pada 24/7/2021, jam 12:09 WIB)

Al-Raqib, Sa’id bin Shalih. (n.d.). https://almoslim.net/node/178678, diakses pada 23/7/2021, pukul 21:14 WIB 